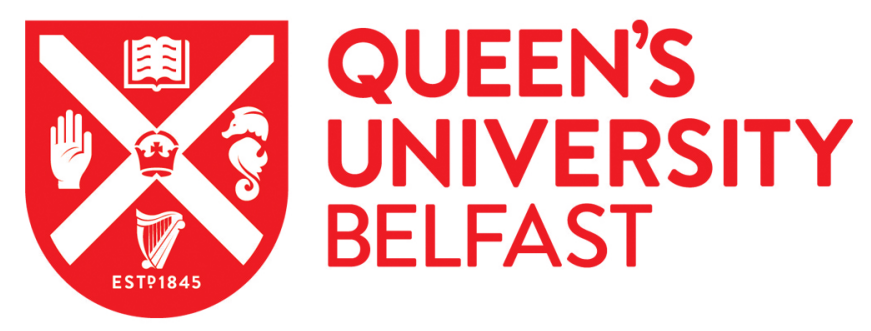

\title{
A systematic review of general practice-based pharmacists' services to optimize medicines management in older people with multimorbidity and polypharmacy
}

Hasan Ibrahim, A. S., Barry, H. E., \& Hughes, C. M. (2021). A systematic review of general practice-based pharmacists' services to optimize medicines management in older people with multimorbidity and polypharmacy. Family Practice, 38(4), 509-523. https://doi.org/10.1093/fampra/cmaa146

Published in:

Family Practice

Document Version:

Peer reviewed version

Queen's University Belfast - Research Portal:

Link to publication record in Queen's University Belfast Research Portal

\section{Publisher rights}

Copyright The Author(s) 2021. Published by Oxford University Press.

This work is made available online in accordance with the publisher's policies. Please refer to any applicable terms of use of the publisher.

\section{General rights}

Copyright for the publications made accessible via the Queen's University Belfast Research Portal is retained by the author(s) and / or other copyright owners and it is a condition of accessing these publications that users recognise and abide by the legal requirements associated with these rights.

Take down policy

The Research Portal is Queen's institutional repository that provides access to Queen's research output. Every effort has been made to ensure that content in the Research Portal does not infringe any person's rights, or applicable UK laws. If you discover content in the

Research Portal that you believe breaches copyright or violates any law, please contact openaccess@qub.ac.uk. 
A systematic review of general practice-based pharmacists' services to optimise medicines management in older people with multimorbidity and polypharmacy

Running/short title: Practice-based pharmacists' services in optimising medicines

management

\section{Article category: Systematic review}

Ameerah S. Hasan Ibrahim ${ }^{a}$, Heather E. Barry ${ }^{\mathrm{a}}$ and Carmel M. Hughes ${ }^{\mathrm{a}, *}$

a Primary Care Research Group, School of Pharmacy, Queen's University Belfast, Belfast, UK

* Correspondence to Prof. Carmel M. Hughes, Primary Care Research Group, School of Pharmacy, Medical Biology

Centre, Queen's University Belfast, 97 Lisburn Road, Belfast, Northern Ireland BT9 7BL, UK; E-mail:

c.hughes@qub.ac.uk

\section{Key Messages}

- Optimising medicines in older people is a major challenge in primary care.

- The role of practice-based pharmacists (PBPs) in this area was evaluated.

- PBPs' interventions had mixed effects on medicines optimisation for older people.

- PBPs' interventions improved outcomes such as prescription appropriateness.

- There had been little or no effect on outcomes e.g. adherence or quality of life.

- Further high-quality research is needed. 


\section{Abstract}

Background: Few studies have evaluated roles of general practice-based pharmacists (PBPs), particularly in optimising medicines management for older people with both multimorbidity and polypharmacy.

Objective: To explore the types and effectiveness of services provided by PBPs, either alone or in collaboration with other primary healthcare professionals, that sought to optimise medicines management for older people with multimorbidity and polypharmacy.

Methods: Eight electronic databases and three trial registries were searched for studies published in English until April 2020. Inclusion criteria were randomised controlled trials, non-randomised controlled trials, and controlled before-and-after studies of services delivered by PBPs in primary care/general practice, for patients aged $\geq 65$ years with both multimorbidity and polypharmacy that focused on a number of outcomes. The Cochrane risk of bias tool for randomised trials (RoB 1 ) and the Risk of Bias in Non-randomised Studies-of Interventions (ROBINS-I) assessment tool were used for quality assessment. A narrative synthesis was conducted due to study heterogeneity.

Results: Seven studies met inclusion criteria. All included studies employed PBP-led medication review accompanied by recommendations agreed and implemented by general practitioners. Other patient-level and practice-level interventions were described in one study. The limited available evidence suggested that PBPs, in collaboration with other practice team members, had mixed effects on outcomes focused on optimising medicines management for older people. Most included studies were of poor quality and data to estimate risk of bias were often missing.

Conclusion: Future high-quality studies are needed to test the effects of PBP interventions on a welldefined range of medicines management-related outcomes.

Key Words: Multimorbidity, older people, polypharmacy, practice-based pharmacists, primary health care, systematic review. 


\section{Lay summary}

Optimising medicines use for older people (aged $\geq 65$ years) with multimorbidity (the presence of two or more long-term conditions) and polypharmacy (the concomitant use of four or more medicines) is urgent due to an ageing population which commonly has complex medications regimens. It is anticipated that pharmacists who have been integrated into general practices [also called practice-based pharmacists (PBPs)] will positively impact on patient outcomes through various roles and activities. As the role of PBPs is relatively new, little is known about the exact nature of their role and how these pharmacists will optimise medicines management for older people in a patient-centred manner. The aim of this research was to provide a detailed understanding of how PBPs may enhance optimisation of medication management in older people and to study the effects of PBPs' interventions on outcomes focused on optimising medicines management for older people with multimorbidity and polypharmacy such as quality of life. The seven included studies indicated that PBP-led interventions such as medication reviews improved a number of outcomes but had either a limited effect or no effect on other outcomes. Further high-quality research is needed in this area. 


\section{Background}

The use of medicines in older people is considered a major healthcare intervention (1). Approximately $67 \%$ of older people are reported to have two or more chronic conditions (multimorbidity), resulting in complex medication regimens $(2,3)$ and polypharmacy (the concomitant use of four or more medicines) $(4,5)$.

Medicines management covers the continuum of how medicines are selected, procured, delivered, prescribed, administered and reviewed to achieve intended outcomes for patients (6). To optimise medicines management, patient-centred care should be achieved through successful healthcare professional co-operation and active engagement of the patient in decision-making about their medicines $(6,7)$. Pharmacists play a key role in improving medication use and management in older people and reducing related risks (8). A systematic review found that pharmacists' interventions can improve patients' outcomes through simplifying the drug regimen, increasing adherence, and preventing adverse drug reactions (ADRs) (9).

High demand for primary care services has emerged from the growing complexity of caring for older people, alongside difficulties in recruiting and retaining staff within the primary care workforce, particularly general practitioners (GPs) and practice nurses, placing general practice under strain (10). To alleviate some of these pressures, pharmacists have been integrated into general practices [also called general practice-based pharmacists (PBPs)] (11).

It is anticipated that PBPs may have a positive impact on patient outcomes through delivery of a range of activities (12). Activities may include medication review (13-15), and conducting medicines reconciliation after hospitalisation (14); these activities are within the usual scope of pharmacist practice (16). However, providing education and drug information (13-15), chronic disease management (e.g. formulating care plans) (16), and performing repeat and independent prescribing are activities undertaken by PBPs (16). 
Some of these activities may require extra study and/or qualifications such as independent prescribing (17), and may also be dependent on the underpinning pharmacy degree which will differ from country to country. To become an independent prescriber in the United Kingdom (UK), registered pharmacists, in addition to their primary pharmacy degree must have at least two years of experience in a UK hospital, community or primary care setting (17). In addition to the UK, independent prescribing by pharmacists may be practised in New Zealand, Canada and the United States, but is not currently within the scope of pharmacist practice in other countries such as Australia (16).

Multiple studies have proposed that more research is required to evaluate the impact of PBPs' services on health- and patient-related outcomes $(13,18-20)$. In addition, previous systematic reviews included studies in which community pharmacists provided non-dispensing services for patients in general practice rather than focusing only on those who were integrated in primary care practices as PBPs $(12,19,21)$. Moreover, those reviews did not focus specifically on optimising medication management for older people $(12,21,22)$. Furthermore, previous reviews that have addressed the effect of pharmacist-led interventions on older people did not focus specifically on those experiencing both polypharmacy and multimorbidity in primary care/general practice $(8,9,23-25)$, with some reviews focused on investigating a specific intervention $(26,27)$, or the effect on a specific outcome $(28-30)$. Therefore, the aim of this review was to understand how PBPs contribute to care of older people by assessing the types and effectiveness of services provided by PBPs, either alone or in collaboration with other healthcare professionals, seeking to optimise medicines management for older people with both polypharmacy and multimorbidity. 


\section{Methods}

This systematic review was conducted in accordance with PRISMA (Preferred Reporting Items for Systematic Reviews and Meta-Analyses) guidelines (31) (Supplementary Material 1). The protocol was registered with the International Prospective Register of Systematic Reviews (PROSPERO; CRD42019122186) (32).

\section{Search strategy}

A systematic search was conducted across eight electronic databases [Ovid Medline, Embase, Scopus, Web of Science, International Pharmaceutical Abstracts, Cumulative Index to Nursing and Allied Health Literature, Cochrane Central Register of Controlled Trials, Cochrane Library] to identify eligible studies published in English from date of inception to April 2020. Three trial registries [Research Registry, International Clinical Trials Registry Platform, ClinicalTrials.gov] were also searched to identify any ongoing or completed clinical trials. Search terms were developed and refined with the assistance of a subject librarian (see Supplementary Material 2 for search strategy). The reference lists of included articles were searched to identify relevant studies.

\section{Study selection}

\section{Types of studies}

Randomised controlled trials (RCTs) including cluster trials, non-randomised controlled trials and controlled before-and-after (CBA) studies were eligible for inclusion in this review.

\section{Types of participants}

All patients aged 65 years or over with both multimorbidity (the presence of two or more long-term conditions) and polypharmacy (the concomitant use of four or more medicines) who presented in primary 
care/general practice and who received services delivered by PBPs were considered. To be considered eligible, studies had to include older people with both multimorbidity and polypharmacy. We accepted studies where the mean age of participants in each study arm was $\geq 65$ years. There were no restrictions on classes of medicines or types of diseases. Residents of care homes were excluded as residents of such facilities do not usually present in person in general practices.

\section{Types of services}

Studies were eligible for inclusion if they involved a service from PBPs, either alone or in collaboration with other healthcare professionals, which affected the outcomes of optimising medicines management for older patients. In addition, studies which analysed the effects of one or more PBPs' services on outcomes were included. The service must have been implemented in primary care/general practice. Primary care settings were defined as either the home of an older person or a GP practice where a PBP provided the service. Care home, ambulatory care and transition care settings were excluded. A comparator/control group was identified as a group of older patients (aged $\geq 65$ years) receiving usual care

(the care as usually received by patients in everyday practice) or no service (no intervention provided for patients).

\section{Types of outcomes}

Included studies needed to report at least one outcome resulting from optimising medicines management in older people by PBPs. Outcomes were categorised as either primary (medicine-related problems, prescription appropriateness, adherence to medicine) or secondary (number of medicines, medicine safety, patient satisfaction, quality of life, shared decision-making between patients and healthcare professionals (e.g. GP, PBP), admissions and readmissions to hospital related to medicines usage). However, we also present other reported outcomes across the included studies to provide an overview of all outcomes resulting from optimising medicines management by PBPs. 


\section{Screening process}

After removing duplicates, two reviewers $(\mathrm{CH}$ and $\mathrm{AHI})$ independently screened titles and abstracts of retrieved articles to identify potential studies. Full-texts of potential studies were also read independently by two reviewers ( $\mathrm{CH}$ and $\mathrm{AHI}$ ) to assess if they met inclusion criteria. After that, both reviewers discussed their results to resolve any discrepancies and a third reviewer (HB) was consulted if consensus could not be reached.

\section{Data extraction and synthesis}

Two review authors ( $\mathrm{AHI}$, and either $\mathrm{HB}$ or $\mathrm{CH}$ ) independently performed data extraction using the Cochrane data collection form as a template (33). Discrepancies between authors were resolved through discussion. Corresponding authors were contacted if key data were missing. The heterogeneity of reported outcomes across the included studies meant that meta-analysis was not possible. Therefore, it was decided to conduct a descriptive narrative synthesis using the extracted data.

\section{Quality assessment}

Two review authors ( $\mathrm{AHI}$, and either $\mathrm{HB}$ or $\mathrm{CH}$ ) independently assessed risk of bias in each included $\mathrm{RCT}$ using the Cochrane Collaboration Risk of Bias assessment tool (RoB 1) (34). The Risk of Bias in Nonrandomised Studies-of Interventions (ROBINS-I) assessment tool (35) was used to assess risk of bias in the CBA study. Disagreements were resolved by consensus, and another review author was consulted to resolve disagreements if necessary. 


\section{Results}

\section{Study selection}

A total of 8,107 articles were retrieved until January 2019. The search was updated in April 2020 and an additional 832 articles were retrieved. Full-texts of 318 articles were assessed for eligibility, and seven articles (six RCTs and one CBA study) were deemed eligible for inclusion (Figure 1) (see Supplementary Material 3 for a list of excluded studies reviewed and reasons for exclusion).

\section{Study characteristics}

The studies were heterogeneous in terms of intervention duration, patient characteristics, number of settings, data analysis, measured outcomes, and follow-up periods (Table 1). The studies, published between 2001 and 2019, were conducted in five countries: three in the UK (36-38) and one each in Canada (39), Sweden (40), Spain (41), and the Netherlands (42). Length of follow-up periods in the studies ranged from 3 months to 6.2 years. Moreover, the total number of medications taken by patients in intervention groups (range 4-11.1), as well as the number of chronic conditions of intervention groups (range 2-5.3), differed among the studies (Table 1). The median sample size was 503 (range 141-11,928).

\section{Characteristics of interventions}

PBPs delivered the interventions either alone $(n=5)$ or in collaboration with other practice team members (e.g. nurse practitioners) ( $n=2$ ). All studies considered medication review for evaluating and optimising patients' medication regimens. After the medication reviews, different recommendations (e.g. starting, discontinuing, or changing medications) were suggested to patients' GPs, which were either accepted or rejected, and agreed recommendations were then finalised, discussed with patients and implemented. Only the CBA study (42) reported that the PBP offered both patient-level (medication reconciliations; individual consultations for patients with specific drug therapy problems) and practice-level (organisation 
of quality improvement projects to recognise and treat patients at risk of medication errors; education of GPs involved and staff members) interventions.

The interventions differed in terms of the specific aims, degree of patient involvement, level of patient contact, level of discussion between PBPs and other practice team members, and patient data sources (Table 1). In the study by Krska et al. (36), the PBP developed a pharmaceutical care plan documenting all pharmaceutical care issues ( $\mathrm{PCls}$; e.g. ADRs) for patients using information from practice computer records and prescriptions, as well as interviews with patients in their own homes. Hogg et al. (39) evaluated if collaborative care provided by the multidisciplinary team involving nurse practitioners, a PBP and a GP improved quality of care for older patients. Lowrie et al. (37) evaluated if a PBP-delivered intervention would reduce hospital admission for deteriorating heart failure or death by optimising medical treatments according to guidelines in left ventricular systolic dysfunction patients. Lenander et al. (40) assessed whether the PBP could decrease the number of drugs and the number of drug-related problems (DRPs). PBPs performed the medication review by checking patient records and all patients were sent a questionnaire to ask about their medications. Campins et al. (41) evaluated the effectiveness and safety of PBPs carrying out assessments to all medications prescribed to each patient in electronic primary care clinical histories using the Good Palliative-Geriatric Practice (GP-GP) algorithm and the Screening Tool of Older Person's Prescriptions (STOPP)/Screening Tool to Alert doctors to Right Treatment (START). Salisbury et al. (38) evaluated if a comprehensive 3D review provided by a nurse, a PBP, and a physician would improve health-related quality of life for older patients with multimorbidity. Sloeserwij et al. (42) assessed the effect of PBPs on medication-related hospitalisations in older people using $\geq 5$ chronic medications. 


\section{Effect of interventions on outcomes}

In total, 41 outcomes were reported across the seven studies (Table 1). The number of reported outcomes in each study ranged from three to eight. Protocols or clinical trials registry reports were identified for five studies $(37-39,41,42)$.

\section{Medicines-related problems}

Krska et al. (36) reported the number and percentage of PCls that had been resolved. At baseline, there was an imbalance as the number of $\mathrm{PCl}$ in the control group was significantly greater than in the intervention group. At the 3-month follow-up period, there was a significant difference in the number or percentage of all types of $\mathrm{PCl}$ that were resolved in the intervention group vs. control group.

Lenander et al. (40) found no significant difference between two groups in the change in the number of DRPs during the 12-month follow-up period. Significant changes were seen in the before-and-after comparison in the intervention group, but not in the control group.

\section{Prescription appropriateness}

Campins et al. (41) found a significant increase in medicine discontinuations, dose adjustments and substitutions in the intervention group than in the control group at follow-up periods ( 3,6 and 12 months). Lowrie et al. (37) optimised medications (ACE inhibitors, ARBs, or $\beta$-blockers) of patients with heart failure. There was a significant difference between two groups (intervention vs. usual care) in the changes in these medications (e.g. starting the medications or dose increases) between baseline and end of the first year of follow-up. 


\section{Adherence to medicine}

Campins et al. (41) used the Morisky-Green test to evaluate treatment adherence at baseline, 3 months and 6 months. At baseline, no significant difference between two groups in treatment adherence was found, while at 6 months, adherence was higher in the intervention group. No data were reported at 3 months.

Salisbury et al. (38) assessed medication adherence using the eight-item Morisky Medication Adherence Score. No significant difference between two groups in medication adherence was found at 9 and 15 months.

\section{Number of medicines}

Lenander et al. (40) reported that at baseline, the intervention group used a greater number of medicines than the control group, while after 12 months, there was a mean reduction in the number of medicines per patient in the intervention group but not in the control group.

Campins et al. (41) did not report if there was a significant difference between two groups in the number of restarted drugs after discontinuation at 3, 6 and 12 months. However, they noted that after the intervention, the number of medicines prescribed to patients in the intervention group was reduced significantly compared with the control group.

Salisbury et al. (38) found no evidence that the intervention reduced the number of medicines prescribed at 15 months.

\section{Quality of life}

Four studies reported no significant difference between two groups in quality of life at baseline or at follow-up periods $(31,33,34,36)$. 


\section{Admissions and readmissions to hospital related to medicines usage}

All RCTs found no significant difference in hospital admissions between two groups during follow-up periods, irrespective of cause. Only the CBA study found lower rates of medication-related hospitalisations in the intervention group vs. usual care group, however, no difference was found in the intervention group vs. usual care plus (care provided by GPs and community pharmacists who had trained in performing medication reviews) group (42).

\section{Quality assessment}

The risk-of-bias summary across the studies is shown in Figures 2, 3, and 4. For RCTs, five of the studies were judged to be at high risk of bias $(36,38-41)$, while the sixth study was judged as being of unclear risk of bias (37). Two domains were at high risk of bias in at least two studies: 'blinding of participants and personnel' and 'other bias' domains. Two studies $(36,39)$ were judged as high risk in the 'other bias' domain due to baseline imbalance and contamination of the control arm by GPs seeing patients in both the control and intervention groups. 'Blinding of outcome assessment' was clearly described in three studies (38-40), whilst the remaining studies either inadequately reported blinding or used the PBP to also collect outcome data. Several unclear risks were detected in the domains and it was the highest-rated risk in two domains: 'incomplete outcome data' and 'other bias' (Figure 2).

The CBA study was found to be at moderate risk of bias (42). Six domains were judged to be at low or moderate risk of bias except the domain of 'bias due to missing data' as the information on this domain had not been clearly provided (Figure 4).

\section{Discussion}

This systematic review demonstrated a paucity of evidence with seven studies investigating PBPs' services to optimise medication management for older people with multimorbidity and polypharmacy. PBP 
interventions involved medication reviews followed by various recommendations agreed by GPs and implemented in all included studies. Pharmacist-led medication reviews were also the most commonly identified interventions in previous studies in the literature $(19,43-45)$. There was only one study in which more than one intervention, in addition to medication review, was offered by PBPs (42).

Polypharmacy is known to be associated with a higher probability of inappropriate prescribing among older people (46). Approximately $6-7 \%$ of hospital admissions of the older people are attributable to DRPs and up to $60 \%$ of such admissions could be prevented if medicines were appropriate (47). In two of the included studies $(36,40)$, PBPs' interventions clearly identified and resolved various types of DRPs, especially those related to dosage, prescription problems, patients' information needs and monitoring to prevent adverse drug reactions. Reduction in DRPs for older people following a pharmacist intervention has been observed in various settings such as in care homes (48), domiciliary settings (49) and acute care for elders units (50).

This review also showed that PBP-led medication reviews could enhance the quality of prescribing and medication appropriateness for older people. Making decisions to prescribe appropriate medicines among older people is difficult. These difficulties arise from factors such as age-related changes, several co-morbidities and the number of medicines being prescribed (51). In addition, there is little clinical evidence available about risks and benefits of drugs in older patients (51). A retrospective cohort study revealed that medication review for older patients with polypharmacy provided by a pharmacist in primary care in collaboration with GPs, led to a reduced number of medications and potentially inappropriate medications per patient, and improved adherence to guidelines (52). It is possible that the ability of the pharmacists to prescribe could improve medication appropriateness in older people which may improve clinical outcomes. The first RCT of pharmacist prescribing in the UK identified that pharmacist prescribing may improve chronic pain for patients through medication review (53). However, in the current systematic review, no PBPs were reported to be independent prescribers. 
Polypharmacy is a risk factor for non-adherence among older people which has been linked to higher rates of hospitalisations, increased healthcare costs and medicine wastage (54). Medication review could improve patients' understanding of their drug regimen and perhaps increase adherence. Although improved adherence to medicines in older people is important to achieve optimal clinical patient outcomes (55), only two trials in this review $(38,41)$ investigated treatment adherence as a secondary outcome. A recent Cochrane review recommended that future studies should seek to achieve welldesigned, feasible and long-term effect interventions intended to enhance patient adherence (56).

Polypharmacy is associated with adverse events which may include ADRs, morbidity and mortality (57). All RCTs found no significant effect of medication review on hospital admissions, emergency department (ED) visits and mortality. Most of the trials reported these as secondary outcomes and were not powered to detect any difference. The translation of optimising medication management into a reduction in these outcomes may require a more prolonged intervention over time, longer follow-up period and a larger sample size. Furthermore, these results suggest that, despite there being no significant effect on these outcomes, the interventions were safe.

All included trials $(31,33,34,36)$ which measured quality of life as an outcome found no significant effect of PBPs' interventions on quality of life as many of these studies did not have a sufficient sample size to detect significant changes. A systematic review found that the evidence of impact of pharmacist-led medication review on improving quality of life for older people across all care settings is uncertain (26). This may be due to the heterogeneous nature of the patients in the existing trials and variations in the delivery of care in addition to small sample sizes (26).

The quality of evidence from the included trials was quite poor and critical data for risk of bias assessment were often missing. Reporting of adequate random sequence generation, allocation sequence concealment, and blinding of outcome assessors incompletely or unclearly produced larger estimations 
of intervention effects $(58,59)$. Low quality evidence was observed in other systematic reviews that investigated the impact of pharmacist interventions in primary care $(19,22,60)$. Clay et al. indicated that the quality of published studies demonstrating the impact of pharmacist patient care intervention is poor and they have developed a checklist to enhance the quality of reporting of pharmacist patient care intervention studies (61). Baseline imbalance in some studies potentially weakened the final results and perhaps lowered the overall quality of evidence (62). Moreover, contamination of the control group may have decreased the estimate of an intervention's effect and rejection of an effective intervention as ineffective (63). To avoid 'contamination' between intervention and control groups, cluster trials are often used (63).

Heterogeneity of studies arose from different outcomes reported across the small number of included studies which impeded meta-analysis. This issue has been highlighted in the literature, with the development of Core Outcome Sets (COSs) increasingly encouraged. A COS is defined as a specific set of outcomes that should be measured and reported as a minimum in a particular clinical area (64). This approach can decrease both the heterogeneity of studies and outcome-reporting bias (64).

\section{Strengths and limitations}

This review explored all PBP interventions to optimise medication management and investigated a wide range of pre-specified outcomes, rather than focusing on specific interventions or outcomes. The searches across a wide range of electronic databases and trial registries, along with hand-searching of reference lists, facilitated identification and possible inclusion of a wide range of potential studies. Moreover, abstract screening and data extraction were completed through compliance with best practice. Nevertheless, the review has several limitations. The inclusion of studies only published in English could lead to exclusion of eligible studies in other languages. The paucity of studies and the inability to conduct a meta-analysis weakened the quality of the evidence and it was difficult to draw firm conclusions. Risk of 
bias assessment can be subjective. However, two reviewers independently evaluated the studies, and a third author resolved any discrepancies. Additionally, we did not contact authors to resolve unclear information when judging risk of bias.

\section{Future research and application to practice}

This is the first systematic review to describe how PBPs contribute to optimising medicines management of older people with both multimorbidity and polypharmacy. Future high-quality, well-designed studies are needed to test the effects of PBP interventions provided with multidisciplinary teams on a welldefined range of management-related outcomes. In addition, there is a need to conduct sufficiently powered trials with adequate follow-up and blinding of outcome assessment. This review supports the need for a COS for trials studying the effect of PBPs on medicines management. Indeed, testing and comparing the effect of multiple PBPs' interventions using robust study designs are warranted as no study compared different PBPs' interventions.

\section{Conclusion}

This systematic review assessed the effect of PBPs' interventions on optimising medication management for older people. The review adds to the evidence base regarding the involvement of pharmacists in primary healthcare teams for older people and highlights the impact of integrating pharmacists within primary care/general practice on optimising medicines management for older people. We found that PBPs' interventions had improved a number of outcomes (e.g. reduced the number of medicines-related problems and improved appropriateness of prescribing). However, there was limited effect on the number of medicines prescribed, adherence to medicines, or no effect on other outcomes such as quality of life. These interventions likely caused no harm and seemed to be safe for older people. However, robust conclusions about the effect of PBPs' interventions on optimising medication management for older people could not be drawn due to poor quality of the limited evidence. This highlights the need for future 
high-quality well-designed research to investigate the effect of PBPs on optimising medication management for older people.

\section{Acknowledgements}

The authors thank Ms. Angela Thompson (Queen's University Belfast subject librarian) for her assistance with development of the search strategy.

\section{Declarations}

Funding: Ameerah Hasan Ibrahim is supported by a PhD research scholarship from the Al-Zaytoonah University of Jordan in Jordan. The funder played no role in the design, analysis, or conduct of the study.

Ethical approval: ethical approval was not required for this study.

Conflicts of interest: none.

\section{Data availability statement}

Data derived from a source in the public domain. All data were obtained from published papers. 


\section{References}

1. Avorn J. Medication use in older patients: better policy could encourage better practice. JAMA. 2010; 304(14): 1606-1607.

2. Wimmer BC, Cross AJ, Jokanovic N, et al. Clinical Outcomes Associated with Medication Regimen Complexity in Older People: A Systematic Review. J Am Geriatr Soc. 2017; 65(4): 747-753.

3. Salive ME. Multimorbidity in Older Adults. Epidemiol Rev. 2013; 35(1): 75-83.

4. Masnoon N, Shakib S, Kalisch-Ellett L, Caughey GE. What is polypharmacy? A systematic review of definitions. BMC Geriatr. 2017; 17: 230.

5. Rankin A, Cadogan CA, Patterson SM, et al. Interventions to improve the appropriate use of polypharmacy for older people. Cochrane Database Syst Rev. 2018; 9: CD008165.

6. Duerden M, Avery T, Payne R. Polypharmacy and medicines optimisation: Making it safe and sound. https://www.kingsfund.org.uk/sites/default/files/field/field_publication_file/Understanding-GP-pressures-KingsFund-May-2016.pdf. 2013 (Accessed 22 January 2020).

7. Stewart M. Towards a global definition of patient centred care. BMJ. 2001; 322(7284): 444-445.

8. Lee J, Alshehri S, Kutbi H, Martin J. Optimizing pharmacotherapy in elderly patients: the role of pharmacists. Integr Pharm Res Pract. 2015; 4: 101-111.

9. Chumney EC, Robinson LC. The effects of pharmacist interventions on patients with polypharmacy. Pharm Pract. 2006; 4(3): 103-109.

10. Baird B, Charles A, Honeyman M, Maguire D, Das P. Understanding pressures in general practice. https://www.kingsfund.org.uk/sites/default/files/field/field publication file/Understanding-GP-pressures-KingsFund-May-2016.pdf. 2016 (Accessed 5 January 2020).

11. NHS England. Clinical Pharmacists in General Practice. https://www.england.nhs.uk/gp/gpfv/workforce/buildingthe-general-practice-workforce/cp-gp/. 2016 (Accessed 14 January 2020).

12. Tan ECK, Stewart K, Elliott RA, George J. Pharmacist services provided in general practice clinics: A systematic review and meta-analysis. Res Soc Adm Pharm. 2014; 10(4): 608-622.

13. Gillespie U, Dolovich L, Dahrouge S. Activities performed by pharmacists integrated in family health teams: Results from a web-based survey. Can Pharm J. 2017; 150(6): 407-416.

14. de Barra M, Scott CL, Scott NW, et al. Pharmacist services for non-hospitalised patients. Cochrane Database Syst Rev. 2018; 9: CD013102.

15. Maskrey M, Johnson CF, Cormack J, Ryan M, Macdonald H. Releasing GP capacity with pharmacy prescribing support and New Ways of Working: a prospective observational cohort study. Br J Gen Pract. 2018; 68(675): 735742.

16. Benson H, Lucas C, Benrimoj SI, Williams KA. The development of a role description and competency map for pharmacists in an interprofessional care setting. Int J Clin Pharm. 2019; 41(2): 391-407.

17. Girvin B, Wilson D. Clinical skills training for pharmacists in general practice. Prescriber. 2018; 29(12): 19-25.

18. Freeman C, Cottrell WN, Kyle G, Williams I, Nissen L. Does a primary care practice pharmacist improve the timeliness and completion of medication management reviews? Int J Pharm Pract. 2012; 20(6): 395-401.

19. Riordan DO, Walsh KA, Galvin R, Sinnott C, Kearney PM, Byrne S. The effect of pharmacist-led interventions in optimising prescribing in older adults in primary care: A systematic review. SAGE Open Med. 2016; 4:

205031211665256.

20. Snell R, Langran T, Donyai P. Patient views about polypharmacy medication review clinics run by clinical pharmacists in GP practices. Int J Clin Pharm. 2017; 39(6): 1162-1165. 
21. Hazen ACM, de Bont AA, Boelman $L$, et al. The degree of integration of non-dispensing pharmacists in primary care practice and the impact on health outcomes: A systematic review. Res Soc Adm Pharm. 2018; 14(3): 228240.

22. Hayhoe B, Foley K, Majeed A, Ruzangi J, Greenfield G, Acuyo Cespedes J. Impact of integrating pharmacists into primary care teams on health systems indicators: A systematic review. Br J Gen Pract. 2019; 69(687): 665-674.

23. Spinewine A, Fialová D, Byrne S. The role of the pharmacist in optimizing pharmacotherapy in older people. Drugs Aging. 2012; 29(6): 495-510.

24. Chisholm-Burns MA, Kim Lee J, Spivey CA, Slack M, Herrier RN, Hall-Lipsy E, et al. US pharmacists' effect as team members on patient care: Systematic review and meta-analyses. Med Care. 2010; 48(10): 923-933.

25. Lee JK, Slack MK, Martin J, Ehrman C, Chisholm-Burns M. Geriatric patient care by U.S. pharmacists in healthcare teams: Systematic review and meta-analyses. J Am Geriatr Soc. 2013; 61(7): 1119-1127.

26. Holland R, Desborough J, Goodyer L, Hall S, Wright D, Loke YK. Does pharmacist-led medication review help to reduce hospital admissions and deaths in older people? A systematic review and meta-analysis. $\mathrm{Br} \mathrm{J}$ Clin Pharmacol. 2008; 65(3): 303-316.

27. Ulley J, Harrop D, Ali A, Alton S, Fowler Davis S. Deprescribing interventions and their impact on medication adherence in community-dwelling older adults with polypharmacy: A systematic review. BMC Geriatr. 2019; 19: 15.

28. Thomas R, Huntley AL, Mann M, Huws D, Elwyn G, Paranjothy S, et al. Pharmacist-led interventions to reduce unplanned admissions for older people: A systematic review and meta-analysis of randomised controlled trials. Age Ageing. 2014; 43(2): 174-187.

29. Rollason V, Vogt N. Reduction of polypharmacy in the elderly: A systematic review of the role of the pharmacist. Drugs Aging. 2003; 20(11): 817-832.

30. Castelino RL, Bajorek B V., Chen TF. Targeting suboptimal prescribing in the elderly: A review of the impact of pharmacy services. Ann Pharmacother. 2009; 43(6): 1096-1106.

31. Moher D, Liberati A, Tetzlaff J, Altman DG. Preferred Reporting Items for Systematic Reviews and Meta-Analyses: The PRISMA Statement. PLoS Med. 2009; 6(7): e1000097.

32. Hasan Ibrahim A, Hughes C, Barry H. A systematic review of practice-based pharmacists' services to optimize medicine management in older people with multimorbidity and polypharmacy: protocol. PROSPERO. CRD42019122186. https://www.crd.york.ac.uk/prospero/display record.php?RecordID=122186. 2019 (Accessed 22 January 2020).

33. Cochrane Effective Practice and Organization of Care (EPOC). Screening, data extraction and management. https://epoc.cochrane.org/sites/epoc.cochrane.org/files/public/uploads/Resources-forauthors2017/screening data extraction and management.pdf. 2017 (Accessed 27 January 2020).

34. Higgins JP, Altman DG. Assessing Risk of Bias in Included Studies. Cochrane Handbook for Systematic Reviews of Interventions. 1st edn. West Sussex-England, John Wiley \& Sons, Inc; 2008.

35. Sterne JA, Hernán MA, Reeves BC, et al. ROBINS-I: A tool for assessing risk of bias in non-randomised studies of interventions. BMJ. 2016; 355: i4919.

36. Krska J, Cromarty JA, Arris F, et al. Pharmacist-led medication review in patients over 65: a randomized, controlled trial in primary care. Age Ageing. 2001; 30(3): 205-211.

37. Lowrie R, Mair FS, Greenlaw N, et al. Pharmacist intervention in primary care to improve outcomes in patients with left ventricular systolic dysfunction. Eur Heart J. 2012; 33(3): 314-324.

38. Salisbury C, Man MS, Bower P, et al. Management of multimorbidity using a patient-centred care model: a pragmatic cluster-randomised trial of the 3D approach. Lancet. 2018; 392(10141): 41-50.

39. Hogg W, Lemelin J, Dahrouge S, et al. Randomized controlled trial of Anticipatory and Preventive multidisciplinary Team Care: For complex patients in a community-based primary care setting. Can Fam Physician. 2009; 55(12): 76-85. 
40. Lenander C, Elfsson B, Danielsson B, Midlöv P, Hasselström J. Effects of a pharmacist-led structured medication review in primary care on drug-related problems and hospital admission rates: a randomized controlled trial. Scand J Prim Health Care. 2014; 32(4): 180-186.

41. Campins L, Serra-Prat M, Gózalo I, et al. Randomized controlled trial of an intervention to improve drug appropriateness in community-dwelling polymedicated elderly people. Fam Pract. 2017; 34(1): 36-42.

42. Sloeserwij VM, Hazen ACM, Zwart DLM, et al. Effects of non-dispensing pharmacists integrated in general practice on medication-related hospitalisations. Br J Clin Pharmacol. 2019; 85(10): 2321-2331.

43. Pitkälä $\mathrm{KH}$, Juola AL, Kautiainen $\mathrm{H}$, et al. Education to Reduce Potentially Harmful Medication Use Among Residents of Assisted Living Facilities: A Randomized Controlled Trial. J Am Med Dir Assoc. 2014; 15(12): 892-898.

44. Frankenthal D, Lerman $Y$, Kalendaryev E, Lerman Y. Intervention with the screening tool of older persons potentially inappropriate prescriptions/screening tool to alert doctors to right treatment criteria in elderly residents of a chronic geriatric facility: A randomized clinical trial. J Am Geriatr Soc. 2014; 62(9): 1658-1665.

45. Tecklenborg S, Byrne C, Cahir C, Brown L, Bennett K. Interventions to Reduce Adverse Drug Event-Related Outcomes in Older Adults: A Systematic Review and Meta-analysis. Drugs and Aging. 2020; 37(2): 91-98.

46. Guaraldo L, Cano FG, Damasceno GS, Rozenfeld S. Inappropriate medication use among the elderly: A systematic review of administrative databases. BMC Geriatrics. 2011; 11: 79.

47. Rogers S, Wilson D, Wan S, Griffin M, Rai G, Farrell J. Medication-related admissions in older people: A crosssectional, observational Study. Drugs Aging. 2009; 26(11): 951-961.

48. Alldred DP, Kennedy MC, Hughes C, Chen TF, Miller P. Interventions to optimise prescribing for older people in care homes (Review). 2016; 2: CD009095.

49. Gudi SK, Kashyap A, Chhabra M, Rashid M, Tiwari KK. Impact of pharmacist-led home medicines review services on drug-related problems among the elderly population: a systematic review. Epidemiol Health. 2019; 41: e2019020.

50. Chan WWT, Dahri K, Partovi N, Egan G, Yousefi V. Evaluation of collaborative medication reviews for high-risk older adults. Can J Hosp Pharm. 2018; 71(6): 356-363.

51. Spinewine A, Schmader KE, Barber N, Hughes C, Lapane KL, Swine C, et al. Appropriate prescribing in elderly people: how well can it be measured and optimised?. Lancet. 2007; 370(9582): 173-184.

52. Stuhec M, Gorenc K, Zelko E. Evaluation of a collaborative care approach between general practitioners and clinical pharmacists in primary care community settings in elderly patients on polypharmacy in Slovenia: A cohort retrospective study reveals positive evidence for implementation. BMC Health Serv Res. 2019; $19: 118$.

53. Bruhn H, Bond CM, Elliott AM, et al. Pharmacist-led management of chronic pain in primary care: Results from a randomised controlled exploratory trial. BMJ Open. 2013; 3: e002361.

54. Hughes CM, Cadogan CA, Patton D, Ryan CA. Pharmaceutical strategies towards optimising polypharmacy in older people. Int J Pharm. 2016. 512(2): 360-365.

55. Patton DE, Cadogan CA, Ryan C, et al. Improving adherence to multiple medications in older people in primary care: Selecting intervention components to address patient-reported barriers and facilitators. Heal Expect. 2018; 21(1): 138-148.

56. Nieuwlaat R, Wilczynski N, Navarro T, et al. Interventions for enhancing medication adherence. Cochrane Database Syst Rev. 2014; 11: CD000011.

57. Hajjar ER, Cafiero AC, Hanlon JT. Polypharmacy in elderly patients. Am J Geriatr Pharmacother. 2007; 5(4): 345351.

58. Schulz KF, Chalmers I, Hayes RJ, Altman DG. Empirical Evidence of Bias: Dimensions of Methodological Quality Associated With Estimates of Treatment Effects in Controlled Trials. JAMA J Am Med Assoc. 1995; 273(5): 408412.

59. Dechartres A, Trinquart L, Faber T, Ravaud P. Empirical evaluation of which trial characteristics are associated with treatment effect estimates. J Clin Epidemiol. 2016; 77: 24-37. 
60. Fish A, Watson MC, Bond CM. Practice-based pharmaceutical services: a systematic review. Int J Pharm Pract. 2002; 10(4): 225-233.

61. Clay PG, Burns AL, Isetts BJ, Hirsch JD, Kliethermes MA, Planas LG. PaCIR: A tool to enhance pharmacist patient care intervention reporting. J Am Pharm Assoc. 2019; 59(5): 615-623.

62. Roberts C, Torgerson DJ. Understanding controlled trials. Baseline imbalance in randomised controlled trials. $\mathrm{Br}$ Med J. 1999; 318(7203): 185.

63. Torgerson DJ. Contamination in trials: is cluster randomisation the answer? Education and debate. BMJ. 2001; 322(7282): 355-357.

64. Williamson PR, Altman DG, Blazeby JM, et al. Developing core outcome sets for clinical trials: issues to consider. Trials. 2012; 13: 132. 
Table 1. Characteristics of included studies on the effect of practice-based pharmacists' services on optimising medicines management in older people with multimorbidity and polypharmacy (published between 2001 and 2019)

\begin{tabular}{|c|c|c|c|c|c|c|c|}
\hline $\begin{array}{l}\text { Author, } \\
\text { country }\end{array}$ & $\begin{array}{l}\text { Study } \\
\text { type }\end{array}$ & $\begin{array}{l}\text { Study } \\
\text { settings }\end{array}$ & $\begin{array}{l}\text { Sample } \\
\text { size of } \\
\text { analysed } \\
\text { patients }\end{array}$ & $\begin{array}{l}\text { Intervention } \\
\text { provider }\end{array}$ & $\begin{array}{l}\text { Description of } \\
\text { intervention }\end{array}$ & $\begin{array}{l}\text { Follow- } \\
\text { up } \\
\text { period }\end{array}$ & Measured outcomes \\
\hline \multirow[t]{6}{*}{$\begin{array}{l}\text { Krska et al. } \\
\text { (36), UK }\end{array}$} & \multirow[t]{6}{*}{$\mathrm{RCT}$} & \multirow[t]{6}{*}{$\begin{array}{l}6 \text { General } \\
\text { medical } \\
\text { practices }\end{array}$} & \multirow[t]{6}{*}{332} & \multirow[t]{6}{*}{$\begin{array}{l}\text { Clinically- } \\
\text { trained } \\
\text { pharmacists }\end{array}$} & \multirow{6}{*}{$\begin{array}{l}\text { Intervention group: } \\
\text { PBPs reviewed the } \\
\text { drug therapy of } \\
\text { patients, and care plan } \\
\text { was then developed } \\
\text { and implemented by } \\
\text { PBPs with assistance } \\
\text { from practice staff } \\
\text { Control group: were } \\
\text { similarly interviewed, } \\
\text { and PCls identified, } \\
\text { although no care plan } \\
\text { was developed and } \\
\text { continued to receive } \\
\text { usual care }\end{array}$} & \multirow[t]{6}{*}{$\begin{array}{l}3 \\
\text { months }\end{array}$} & $\begin{array}{l}\text { Presence of PCls (number of PCls and \% of PCls resolved: at baseline: } \\
\text { significantly more PCls were in the control group than in the intervention group } \\
(1380 \text { v. } 1206 ; \mathrm{P}<0.05) \text {. At } 3 \text { months: significant percentage (number) of } \\
\text { remaining } \mathrm{PCl} \text { had been totally resolved in intervention group vs. control } \\
\text { group ( } 70 \% \text { (587) vs. } 14 \%(136) ; P<0.0001\end{array}$ \\
\hline & & & & & & & $\begin{array}{l}\text { Medication costs (at baseline and } 3 \text { months): no significant differences in the } \\
\text { average monthly costs of prescribed medication per patient between groups, } \\
\text { either at initial interview ( } 39.29 \pm 29.07 \text { vs } 42.80 \pm 33.50, P \text { NR ) or after } \\
\text { intervention ( } 38.83 \pm 29.60 \text { vs } 42.61 \pm 31.84, P \text { NR) }\end{array}$ \\
\hline & & & & & & & $\begin{array}{l}\text { Health-related quality of life (at baseline and } 3 \text { months): no significant } \\
\text { differences in any of the scores between two groups at baseline and } 3 \text { months } \\
\text { (figures NR) }\end{array}$ \\
\hline & & & & & & & $\begin{array}{l}\text { Use of health and social services (at baseline and } 3 \text { months): no difference in } \\
\text { hospital clinic attendance, use of social services, and contacts with district } \\
\text { nurses and health visitors between two groups before and after the pharmacist } \\
\text { review (figures NR). Slight increase in contacts with both practice nurses (from } \\
15 \text { to } 28 \text { ) and GPs (from eight to } 22 \text { ) in the intervention group, which was not } \\
\text { seen in the control group ( } P \text { NR) }\end{array}$ \\
\hline & & & & & & & $\begin{array}{l}\text { Use of health and social services (elective and emergency admissions) at } \\
\text { baseline: more elective (13) and emergency admissions ( } 23 \text { ) in intervention } \\
\text { group than the control group (five elective and } 11 \text { emergency admissions) (P } \\
\text { NR). At } 3 \text { months: numbers of elective admissions were similar in both groups } \\
\text { (six intervention, five control). Emergency admissions was decreased by } 74 \% \text { in } \\
\text { the intervention group compared with } 27 \% \text { in the control group, the numbers } \\
\text { were too small for statistics to be meaningful (six emergency admissions vs. } \\
\text { eight emergency admissions: } P \text { NR) }\end{array}$ \\
\hline & & & & & & & $\begin{array}{l}\text { Use of health and social services (number of the patients who received help in } \\
\text { collecting or taking medicines) at baseline and } 3 \text { months: no changes in the } \\
\text { number of patients who received help in collecting or taking medicines in } \\
\text { either group after the intervention ( } 35 \text { vs. } 37, \text { P NR) }\end{array}$ \\
\hline
\end{tabular}


Table 1. Continued

\begin{tabular}{|c|c|c|c|c|c|c|c|}
\hline $\begin{array}{l}\text { Author, } \\
\text { country }\end{array}$ & $\begin{array}{l}\text { Study } \\
\text { type }\end{array}$ & $\begin{array}{l}\text { Study } \\
\text { settings }\end{array}$ & $\begin{array}{l}\text { Sample } \\
\text { size of } \\
\text { analysed } \\
\text { patients }\end{array}$ & $\begin{array}{l}\text { Intervention } \\
\text { provider }\end{array}$ & $\begin{array}{l}\text { Description of } \\
\text { intervention }\end{array}$ & $\begin{array}{l}\text { Follow- } \\
\text { up } \\
\text { period }\end{array}$ & Measured outcomes \\
\hline \multirow[t]{8}{*}{$\begin{array}{l}\text { Hogg et al. } \\
\text { (39), Canada }\end{array}$} & \multirow[t]{8}{*}{ RCT } & \multirow[t]{8}{*}{$\begin{array}{l}\text { One } \\
\text { Family } \\
\text { health } \\
\text { network } \\
\text { (family } \\
\text { practice) }\end{array}$} & \multirow[t]{8}{*}{240} & \multirow{8}{*}{$\begin{array}{l}\text { Anticipatory } \\
\text { and } \\
\text { Preventive } \\
\text { Team Care } \\
\text { (composed of } \\
\text { patients' } \\
\text { physicians, } 1 \\
\text { of } 3 \text { NPs, and } \\
\text { a pharmacist) }\end{array}$} & \multirow{8}{*}{$\begin{array}{l}\text { Intervention group: } \\
\text { PBPs and NPs: } \\
\text { conducted chart } \\
\text { reviews and home } \\
\text { visits for each patient } \\
\text { at the start of the } \\
\text { study. The PBP then } \\
\text { performed a } \\
\text { medication review, to } \\
\text { identify the drug- } \\
\text { related problems and } \\
\text { necessary actions to } \\
\text { address these issues. } \\
\text { NP developed care } \\
\text { plan in collaboration } \\
\text { with the patient and in } \\
\text { discussion with the } \\
\text { PBP and the patient's } \\
\text { GP } \\
\text { Control group: usual } \\
\text { care }\end{array}$} & \multirow{8}{*}{$\begin{array}{l}12 \text { to } \\
18 \\
\text { months } \\
\text { (mean } \\
\text { of } 14.9 \\
\text { months } \\
\text { in each } \\
\text { arm) }\end{array}$} & $\begin{array}{l}\text { Quality of care for chronic disease management in } 4 \text { conditions (i.e., diabetes, } \\
\text { coronary artery disease, congestive heart failure and chronic obstructive } \\
\text { pulmonary disease): significant increase in the quality of care for chronic } \\
\text { disease management in intervention group compared with control group } \\
\text { (absolute difference of } 9.1 \%, 95 \% \mathrm{Cl} 3.7 \% \text { to } 14.4 \% ; P<0.001 \text { ) }\end{array}$ \\
\hline & & & & & & & $\begin{array}{l}\text { Quality of preventive care: significant improvement in preventive care by } \\
16.5 \%(P<0.001) \text { in intervention group compared with control group. An } 18.1 \% \\
(95 \% \mathrm{Cl} 10.8 \% \text { to } 25.5 \%) \text { absolute difference in prevention was observed } \\
\text { between two groups }\end{array}$ \\
\hline & & & & & & & $\begin{array}{l}\text { Intermediate clinical outcomes: no significant difference in intermediate } \\
\text { clinical outcome measures between two groups }(P \geq 0.071)\end{array}$ \\
\hline & & & & & & & $\begin{array}{l}\text { Quality of life: -no significant differences in scores of Short-Form } 36 \text { between } \\
\text { two groups [Physical component, score out of } 100 \text { (D1 } 2.7 \text { vs. D2 } 1.1 \text {, D1-D2 } \\
\text { 1.6; } 95 \% \mathrm{Cl}-0.8 \text { to } 4.1 ; P=0.18 \text { ), Mental component, score out of } 100 \text { (D1 }-1.2 \\
\text { vs. D2 -0.1, D1-D2 }-1.1 ; 95 \% \mathrm{Cl}-3.7 \text { to } 1.6 ; P=0.44 \text { )] } \\
\text {-no significant differences in scores of health-related quality-of-life scales } \\
\text { between two groups (Self-assessed poor or fair health, \% (D1 3.6 VS. D2 3.5, } \\
\text { D1-D2 } 0.1 ; 95 \% \mathrm{Cl}-12.8 \text { to } 13.1 ; P=0.98 \text { ), No. of unhealthy days in last } 30 \text { days } \\
\text { (D1 -1.0 VS. D2 } 0.4, \mathrm{D} 1-\mathrm{D} 2-1.4 ; 95 \% \mathrm{Cl}-4.5 \text { to } 1.8 ; P=0.39 \text { ) }\end{array}$ \\
\hline & & & & & & & $\begin{array}{l}\text { Functional status: no significant difference in score of Instrumental activities of } \\
\text { daily living, score out of } 31 \text {, between two groups (D1 } 0.3 \text { vs.D2 } 0.6 \text {, D1-D2 -0.3; } \\
95 \% \mathrm{Cl}-1.1 \text { to } 0.5 ; P=0.50 \text { ) }\end{array}$ \\
\hline & & & & & & & $\begin{array}{l}\text { Service usage (emergency use): no significant difference in emergency use } \\
\text { between two groups [any emergency department visit,\% of patients (D1 } 38 \\
\text { vs.D2 42, D1-D2 -4; } 95 \% \mathrm{Cl}-16.4 \text { to } 8.4 ; P=0.46 \text { ), average no. of ED visits (D1 } \\
0.63 \text { vs.D2 } 0.73 \text {, D1-D2 }-0.10 ; 95 \% \mathrm{Cl}-0.38 \text { to } 0.18 ; P=0.48 \text { )] }\end{array}$ \\
\hline & & & & & & & $\begin{array}{l}\text { Service usage (hospitalization): no significant difference in hospital admission } \\
\text { between two groups [any hospital admission, \% of patients (D1 } 26 \text { vs.D2 26, } \\
\text { D1-D2 0; } 95 \% \mathrm{Cl}-11.1 \text { to } 11.1 ; P=0.97 \text { ), average no. of hospital admissions (D1 } \\
0.40 \text { vs.D2 } 0.46 \text {, D1-D2 }-0.06 ; 95 \% \mathrm{Cl}-0.31 \text { to } 0.2 ; P=0.67 \text { )] }\end{array}$ \\
\hline & & & & & & & $\begin{array}{l}\text { Caregiver burden score out of } 88 \text { : no significant difference in the score } \\
\text { between groups (D1 } 1.7 \text { vs. D2 -3.3,D1-D2 5.0; } 95 \% \mathrm{Cl} 1.4 \text { to } 8.6 ; P=0.007\end{array}$ \\
\hline
\end{tabular}


Table 1. Continued

\begin{tabular}{|c|c|c|c|c|c|c|c|}
\hline $\begin{array}{l}\text { Author, } \\
\text { country }\end{array}$ & $\begin{array}{l}\text { Study } \\
\text { type }\end{array}$ & $\begin{array}{l}\text { Study } \\
\text { settings }\end{array}$ & $\begin{array}{l}\text { Sample } \\
\text { size of } \\
\text { analysed } \\
\text { patients }\end{array}$ & $\begin{array}{l}\text { Intervention } \\
\text { provider }\end{array}$ & $\begin{array}{l}\text { Description of } \\
\text { intervention }\end{array}$ & $\begin{array}{l}\text { Follow- } \\
\text { up } \\
\text { period }\end{array}$ & Measured outcomes \\
\hline \multirow[t]{8}{*}{$\begin{array}{l}\text { Lowrie et al. } \\
\text { (37), UK }\end{array}$} & \multirow[t]{8}{*}{$\begin{array}{l}\text { Cluster } \\
\text { RCT }\end{array}$} & \multirow{8}{*}{$\begin{array}{l}\text { Intervention } \\
\text { in } 87 \text { general } \\
\text { practices } \\
\text { and usual } \\
\text { care in } \\
\text { another } 87 \\
\text { general } \\
\text { practices }\end{array}$} & \multirow[t]{8}{*}{2164} & \multirow{8}{*}{$\begin{array}{l}\text { Non-specialist } \\
\text { primary care- } \\
\text { based } \\
\text { pharmacists }\end{array}$} & \multirow{8}{*}{$\begin{array}{l}\text { Intervention group: } \\
\text { were offered a 30-min } \\
\text { appointment with a } \\
\text { PBP. If there was } \\
\text { agreement between } \\
\text { the PBP and the } \\
\text { patient during the } \\
\text { consultation and later } \\
\text { with the GP, } \\
\text { medications were } \\
\text { started, discontinued, } \\
\text { or changed } \\
\text { Control group: usual } \\
\text { care }\end{array}$} & \multirow{8}{*}{$\begin{array}{l}\text { Median } \\
: 4.7 \\
\text { years } \\
\text { (range } \\
6 \text { days } \\
\text { to } 6.2 \\
\text { years) }\end{array}$} & $\begin{array}{l}\text { Death from any cause or hospital admission for heart failure: no significant } \\
\text { difference in patients with event between two groups ( } 35.8 \% \text { vs. } 35.4 \% \text {, } \\
\text { adjusted HR } 0.97,95 \% \mathrm{Cl} 0.83 \text { to } 1.14 \text {; adjusted } P=0.72 \text { ) }\end{array}$ \\
\hline & & & & & & & $\begin{array}{l}\text { Death from any cause or admission for cardiovascular cause: no significant } \\
\text { difference in patients with event between two groups ( } 45 \% \text { vs. } 44 \% \text {, adjusted } \\
\text { HR } 0.97,95 \% \mathrm{Cl} 0.83 \text { to } 1.12 \text {; adjusted } P=0.70)\end{array}$ \\
\hline & & & & & & & $\begin{array}{l}\text { Death from any cause or admission for any reason: no significant difference in } \\
\text { patients with event between two groups ( } 70 \% \text { vs. } 70 \% \text {, adjusted HR } 0.96,95 \% \\
\mathrm{Cl} 0.86 \text { to } 1.07 \text {; adjusted } P=0.41 \text { ) }\end{array}$ \\
\hline & & & & & & & $\begin{array}{l}\text { Number of patients admitted to hospital for heart failure, cardiovascular } \\
\text { causes, and any reason: no significant difference in patients with event } \\
\text { between two groups (for heart failure: } 107 \text { vs. } 114 \text {, adjusted HR } 0.88,95 \% \mathrm{Cl} \\
0.67 \text { to } 1.16 \text {; adjusted } P=0.36 \text {, for cardiovascular causes: } 292 \text { vs. } 280 \text {, adjusted } \\
\text { HR } 0.98,95 \% \mathrm{Cl} 0.81 \text { to } 1.19 \text {; adjusted } P=0.83 \text {, for any cause: } 711 \text { vs. } 695 \text {, } \\
\text { adjusted HR } 0.97,95 \% \mathrm{Cl} 0.87 \text { to } 1.09 \text {; adjusted } P=0.61 \text { ) }\end{array}$ \\
\hline & & & & & & & $\begin{array}{l}\text { Total numbers of hospital admissions (including second and subsequent } \\
\text { hospital admissions) for heart failure, cardiovascular causes, and any reason: } \\
\text { no significant difference in total number of hospital admissions between two } \\
\text { groups (for heart failure: } 149 \text { vs. } 194 \text { ( } P=0.08) \text {, for cardiovascular causes: } 474 \\
\text { vs. } 517(\mathrm{P}=0.19) \text {, for any reason: } 2205 \text { vs. } 2191(\mathrm{P}=0.84)\end{array}$ \\
\hline & & & & & & & $\begin{array}{l}\text { Death from any cause: no significant difference in patients with event between } \\
\text { two groups ( } 337 \text { ( } 31 \%) \text { vs. } 331 \text { ( } 31 \%) \text {, adjusted HR 0.96, } 95 \% \mathrm{Cl} 0.80 \text { to 1.16; } \\
\text { adjusted } P=0.68)\end{array}$ \\
\hline & & & & & & & $\begin{array}{l}\text { Healthcare utilization (e.g. the number of primary care contacts and hospital } \\
\text { emergency room visits): no significant difference in any aspect of healthcare } \\
\text { utilization at } 1 \text { and } 2 \text { years of follow up, all figures reported in supplementary } \\
\text { material online and all P values }>0.05\end{array}$ \\
\hline & & & & & & & $\begin{array}{l}\text { Prescribing of medications: Treatment was started, or the dose increased in } \\
\text { patients not receiving one or other of } \mathrm{ACE} \text { inhibitor or ARB or receiving less } \\
\text { than the recommended dose ( } 33.1 \% \text { vs. } 18.5 \% \text {; OR } 2.26 ; 95 \% \mathrm{Cl} 1.64 \text { to } 3.10 \text {; } \\
\mathrm{P}<0.001 \text { ) } \\
\text { - Treatment was started, or the dose increased in patients not receiving a } \beta \text { - } \\
\text { blocker ( } 17.9 \% \text { vs. } 11.1 \% \text {; OR } 1.76 ; 95 \% \mathrm{Cl} 1.31 \text { to } 2.35 ; \mathrm{P}<0.001 \text { ) }\end{array}$ \\
\hline
\end{tabular}


Table 1. Continued

\begin{tabular}{|c|c|c|c|c|c|c|c|}
\hline $\begin{array}{l}\text { Author, } \\
\text { country }\end{array}$ & $\begin{array}{l}\text { Study } \\
\text { type }\end{array}$ & $\begin{array}{l}\text { Study } \\
\text { settings }\end{array}$ & $\begin{array}{l}\text { Sample } \\
\text { size of } \\
\text { analysed } \\
\text { patients }\end{array}$ & $\begin{array}{l}\text { Intervention } \\
\text { provider }\end{array}$ & $\begin{array}{l}\text { Description of } \\
\text { intervention }\end{array}$ & $\begin{array}{l}\text { Follow- } \\
\text { up } \\
\text { period }\end{array}$ & Measured outcomes \\
\hline \multirow[t]{5}{*}{$\begin{array}{l}\text { Lenander et } \\
\text { al. (40), } \\
\text { Sweden }\end{array}$} & \multirow[t]{5}{*}{$\mathrm{RCT}$} & \multirow[t]{5}{*}{$\begin{array}{l}\text { One primary } \\
\text { care centre }\end{array}$} & \multirow[t]{5}{*}{141} & \multirow[t]{5}{*}{$\begin{array}{l}\text { Certified } \\
\text { geriatric } \\
\text { pharmacist }\end{array}$} & \multirow{5}{*}{$\begin{array}{l}\text { Intervention group: } \\
\text { the PBP reviewed all } \\
\text { medications regarding } \\
\text { recommendations and } \\
\text { giving pharmaceutical } \\
\text { advice to patients } \\
\text { Control group: usual } \\
\text { care }\end{array}$} & \multirow[t]{5}{*}{$\begin{array}{l}12 \\
\text { months }\end{array}$} & $\begin{array}{l}\text { Number of drugs: significant difference in the change in the number of drugs } \\
\text { between two groups } P<0.046 \text { (at baseline: } 8.6 ; 95 \% \mathrm{Cl} 7.8 \text { to } 9.3 ; \text { vs. } 7.4 ; 95 \% \mathrm{Cl} \\
6.9 \text { to } 8.0 \text {, at } 12 \text { month follow up: } 7.9 ; 95 \% \mathrm{Cl} 0.10 \text { to } 0.75 \text { vs. } 7.5 ; 95 \% \mathrm{Cl}-0.02 \\
\text { to } 0.57 \text { ) }\end{array}$ \\
\hline & & & & & & & $\begin{array}{l}\text { Drug-related problems: - no significant difference in the change in the number } \\
\text { of drug-related problems } P=0.72 \text { (at baseline: } 1.73 ; 95 \% \mathrm{Cl} 1.42 \text { to } 2.05 \text { vs. } \\
1.37 ; 95 \% \mathrm{Cl} 1.07 \text { to } 1.69 \text {, at } 12 \text { month follow up: } 1.31 ; 95 \% \mathrm{Cl} 1.02 \text { to } 1.59 \text { vs. } \\
1.11 ; 95 \% \mathrm{Cl} 0.84 \text { to } 1.37 \text { ) } \\
\text {-a significant decrease in the number of drug-related problems before-and- } \\
\text { after the intervention in the intervention group only (from } 1.73 ; 95 \% \mathrm{Cl} 1.42 \text { to } \\
2.05 \text { at baseline to } 1.31 ; 95 \% \mathrm{Cl} 1.02 \text { to } 1.59 \text { at } 12 \text {-month follow-up, } P=0.02 \text { ) }\end{array}$ \\
\hline & & & & & & & $\begin{array}{l}\text { Utilization of medical care: no significant difference between the two groups } \\
\text { during } 12 \text { month follow-up regarding the mean number of primary care visits } \\
\text { (1.6; } 95 \% \mathrm{Cl} 0.8 \text { to } 1.3 \text { vs. } 1.4 ; 95 \% \mathrm{Cl} 0.7 \text { to } 14, P \text { NR), mean length of } \\
\text { hospitalization (days) ( } 12 \text { vs. } 18, P \text { NR), and mean number of admissions to } \\
\text { hospital ( } 1.7 \text { vs. } 2.7, P \text { NR) }\end{array}$ \\
\hline & & & & & & & $\begin{array}{l}\text { Self-rated health: significant difference in change in self-rated health between } \\
\text { the two groups }(0.02 ; 95 \% \mathrm{Cl}-0.15 \text { to } 0.19 \text { vs. } 0.27 ; 95 \% \mathrm{Cl} 0.06 \text { to } 0.48 \text {, } \\
P=0.047) \text { at } 12 \text {-month follow-up }\end{array}$ \\
\hline & & & & & & & $\begin{array}{l}\text { Estimated cost of the intervention: the cost of implementing this intervention } \\
\text { in everyday practice was estimated at } € 79(\$ 106) \text { per patient, based on the } \\
\text { estimated total cost of one clinically trained, experienced pharmacist }\end{array}$ \\
\hline
\end{tabular}


Table 1. Continued

\begin{tabular}{|c|c|c|c|c|c|c|c|}
\hline $\begin{array}{l}\text { Author, } \\
\text { country }\end{array}$ & $\begin{array}{l}\text { Study } \\
\text { type }\end{array}$ & $\begin{array}{l}\text { Study } \\
\text { settings }\end{array}$ & $\begin{array}{l}\text { Sample } \\
\text { size of } \\
\text { analysed } \\
\text { patients }\end{array}$ & $\begin{array}{l}\text { Intervention } \\
\text { provider }\end{array}$ & $\begin{array}{l}\text { Description of } \\
\text { intervention }\end{array}$ & $\begin{array}{l}\text { Follow- } \\
\text { up } \\
\text { period }\end{array}$ & Measured outcomes \\
\hline \multirow[t]{7}{*}{$\begin{array}{l}\text { Campins et } \\
\text { al. (41), } \\
\text { Spain }\end{array}$} & \multirow[t]{7}{*}{$\mathrm{RCT}$} & \multirow[t]{7}{*}{$\begin{array}{l}7 \text { primary } \\
\text { healthcare } \\
\text { centres }\end{array}$} & \multirow[t]{7}{*}{503} & \multirow[t]{7}{*}{$\begin{array}{l}\text { A trained and } \\
\text { experienced } \\
\text { clinical } \\
\text { pharmacist }\end{array}$} & \multirow{7}{*}{$\begin{array}{l}\text { Intervention group: } \\
\text { PBP reviewed of all } \\
\text { medication according } \\
\text { to the GP-GP } \\
\text { algorithm and the } \\
\text { STOPP/START criteria } \\
\text { and then discussed } \\
\text { recommendations for } \\
\text { each drug with the } \\
\text { GPs. A final decision } \\
\text { was agreed by GPs } \\
\text { and their patients in a } \\
\text { face-to-face visit } \\
\text { Control group: usual } \\
\text { care }\end{array}$} & \multirow[t]{7}{*}{$\begin{array}{l}\text { At } 3,6 \text {, } \\
12 \\
\text { months }\end{array}$} & $\begin{array}{l}\text { Number of medications prescribed at } 3,6 \text { and } 12 \text { months: number of drugs } \\
\text { discontinued, dose adjusted or substituted per patient at } 3,6,12 \text { months or } \\
\text { the percentage of patients with at least one medication discontinued, dose } \\
\text { adjusted or substituted were significantly higher in the intervention group than } \\
\text { in the control group at } 3,6 \text { and } 12 \text { months }(P<0.001)\end{array}$ \\
\hline & & & & & & & $\begin{array}{l}\text { Number of restarted drugs at } 3,6 \text { and } 12 \text { months: the number of intervention } \\
\text { group-restarted drugs at } 3,6 \text { and } 12 \text { months were } 12.0 \%, 15.9 \% \text { and } 17.3 \% \text {, } \\
\text { respectively. Control group-restarted drugs were } 5.7 \% \text { and } 11.3 \% \text { at } 6 \text { and } 12 \\
\text { months, respectively; restarts at } 3 \text { months could not be calculated as there } \\
\text { were no baseline discontinuations ( } P \text { NR) }\end{array}$ \\
\hline & & & & & & & $\begin{array}{l}\text { New prescriptions: no differences were observed at } 3,6 \text { and } 12 \text { months } \\
\text { between the control group ( } 120,78 \text { and } 208 \text { prescriptions, respectively) and } \\
\text { intervention groups ( } 135,62 \text { and } 209 \text { prescriptions, respectively) (P NR) }\end{array}$ \\
\hline & & & & & & & $\begin{array}{l}\text { Treatment adherence at baseline, } 3 \text {-month and } 6 \text {-month: - at baseline: no } \\
\text { significant differences were observed between two groups in initial treatment } \\
\text { adherence ( } 61.8 \% \text { in the intervention group vs. } 60.2 \% \text { in the control group; } \\
P=0.713) \text {; - at } 3 \text { months: figures NR - at } 6 \text { months: adherence was higher in the } \\
\text { intervention group ( } 76.4 \% \text { versus } 64.1 \% ; P=0.005 \text { ) }\end{array}$ \\
\hline & & & & & & & $\begin{array}{l}\text { Number of primary care visits per patient: Significant differences were } \\
\text { observed between two groups in the mean number of primary care visits at } 3 \\
\text { months }(7.32 \pm 5.48 \text { vs. } 6.02 \pm 4.69, P=0.001 \text { ) and } 6 \text { months }(12.92 \pm 9.59 \text { vs. } \\
11.4 \pm 8.01, P=0.048 \text { ) but not at } 12 \text { months ( } 24.0 \pm 16.8 \text { vs. } 23.0 \pm 14.1 \text {, } \\
P=0.670 \text { ) }\end{array}$ \\
\hline & & & & & & & $\begin{array}{l}\text { Number of hospital emergency visits per patient: no significant differences } \\
\text { were observed between two groups in mean number of emergency } \\
\text { department visits during the entire follow-up period [at } 3 \text { months }(0.27 \pm 0.94 \\
\text { vs. } 0.22 \pm 0.53, P=0.726) \text {, at } 6 \text { months }(0.47 \pm 1.02 \text { vs. } 0.43 \pm 0.81, P=0.985) \text {, at } \\
12 \text { months }(0.9 \pm 1.5 \text { vs. } 1.1 \pm 1.5, P=0.061) \text { ] }\end{array}$ \\
\hline & & & & & & & $\begin{array}{l}\text { Number of specialty care visits per patient: no significant differences were } \\
\text { observed between two groups in number of specialty care visits per patient } \\
\text { during the entire follow-up period [at } 3 \text { months }(1.50 \pm 2.12 \text { vs. } 1.61 \pm 2.41 \text {, } \\
P=0.986) \text {, at } 6 \text { months }(2.89 \pm 3.46 \text { vs. } 2.81 \pm 3.61, P=0.253) \text {, at } 12 \text { months (6.9 } \\
\pm 7.3 \text { vs. } 6.8 \pm 7.6, P=0.302) \text { ] }\end{array}$ \\
\hline
\end{tabular}




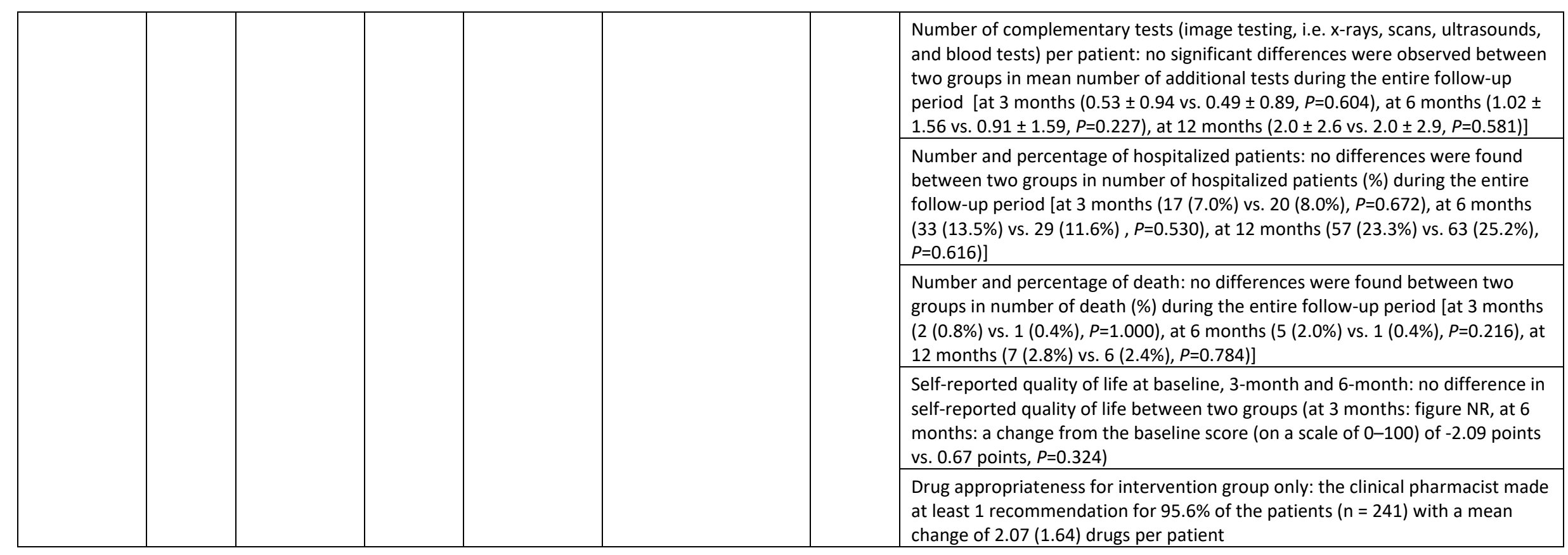


Table 1. Continued

\begin{tabular}{|c|c|c|c|c|c|c|c|}
\hline $\begin{array}{l}\text { Author, } \\
\text { country }\end{array}$ & $\begin{array}{l}\text { Study } \\
\text { type }\end{array}$ & $\begin{array}{l}\text { Study } \\
\text { settings }\end{array}$ & $\begin{array}{l}\text { Sample } \\
\text { size of } \\
\text { analysed } \\
\text { patients }\end{array}$ & $\begin{array}{l}\text { Intervention } \\
\text { provider }\end{array}$ & $\begin{array}{l}\text { Description of } \\
\text { intervention }\end{array}$ & $\begin{array}{l}\text { Follow- } \\
\text { up } \\
\text { period }\end{array}$ & Measured outcomes \\
\hline \multirow[t]{4}{*}{$\begin{array}{l}\text { Salisbury et } \\
\text { al. (38), UK }\end{array}$} & \multirow[t]{4}{*}{$\begin{array}{l}\text { Cluster } \\
\text { RCT }\end{array}$} & \multirow{4}{*}{$\begin{array}{l}\text { Intervention } \\
\text { in } 16 \text { general } \\
\text { practices } \\
\text { and usual } \\
\text { care in } \\
\text { another } 17 \\
\text { general } \\
\text { practices }\end{array}$} & \multirow[t]{4}{*}{1546} & \multirow{4}{*}{$\begin{array}{l}\text { Each 6- } \\
\text { monthly 3D } \\
\text { review } \\
\text { consisted of a } \\
\text { review by a } \\
\text { nurse, a } \\
\text { physician, and } \\
\text { a pharmacist. } \\
\text { A two half- } \\
\text { days of } \\
\text { training were } \\
\text { received by } \\
\text { healthcare } \\
\text { professionals } \\
\text { involved in } \\
\text { the study }\end{array}$} & \multirow{4}{*}{$\begin{array}{l}\text { Intervention group: } \\
\text { comprehensive } \\
\text { multidisciplinary 3D } \\
\text { review (nurse review } \\
\text { e.g. identified the } \\
\text { health problems most } \\
\text { important to the } \\
\text { patient, pharmacist } \\
\text { review i.e. reviewed } \\
\text { medication and made } \\
\text { recommendations } \\
\text { about simplifying drug } \\
\text { regimen, physician } \\
\text { review i.e. considered } \\
\text { the nurse and } \\
\text { pharmacist reviews } \\
\text { and agreed health } \\
\text { plans with the patient } \\
\text { Control group: usual } \\
\text { care }\end{array}$} & \multirow[t]{4}{*}{$\begin{array}{l}\text { At } 9,15 \\
\text { months }\end{array}$} & $\begin{array}{l}\text { Health-related quality of life: no significant difference in mean EQ-5D-5L score } \\
\text { between two groups (at } 9 \text { months (adjusted mean difference } 0.01,95 \% \mathrm{Cl}-0.01 \\
\text { to } 0.03 ; P=0.53 \text { ), at } 15 \text { months (adjusted mean difference } 0.00,95 \% \mathrm{Cl}-0.02 \text { to } \\
0.02 ; P=0.93 \text { )) }\end{array}$ \\
\hline & & & & & & & $\begin{array}{l}\text { Illness burden: no significant difference between two groups in measuring of } \\
\text { illness burden [self-rated health of good or better: at } 9 \text { months (adjusted mean } \\
\text { difference } 0.95,95 \% \mathrm{Cl} 0.76 \text { to } 1.19 ; P=0.66 \text { ), at } 15 \text { months (adjusted mean } \\
\text { difference } 0.84,95 \% \mathrm{Cl} 0.67 \text { to } 1.05 ; P=0.13 \text { ), Bayliss measure of illness burden: } \\
\text { at } 9 \text { months (adjusted mean difference } 0.30,95 \% \mathrm{Cl}-0.65 \text { to } 1.26 ; P=0.54 \text { ), at } \\
15 \text { months (adjusted mean difference }-0.64,95 \% \mathrm{Cl}-1.54 \text { to } 0.27 ; P=0.17 \text { ), } \\
\text { HADS anxiety score: at } 9 \text { months (adjusted mean difference }-0.18,95 \% \mathrm{Cl}-0.50 \\
\text { to } 0.14 ; P=0.26 \text { ), at } 15 \text { months (adjusted mean difference }-0.24,95 \% \mathrm{Cl}-0.57 \text { to } \\
0.08 ; P=0.15 \text { ), HADS depression score: at } 9 \text { months (adjusted mean difference } \\
0.07,95 \% \mathrm{Cl}-0.22 \text { to } 0.36 ; P=0.65 \text { ), at } 15 \text { months (adjusted mean difference - } \\
0.01,95 \% \mathrm{Cl}-0.33 \text { to } 0.30 ; P=0.94 \text { )] }\end{array}$ \\
\hline & & & & & & & $\begin{array}{l}\text { Treatment burden: no significant difference between two groups in measuring } \\
\text { of treatment burden (Multimorbidity Treatment Burden Questionnaire score: } \\
\text { at } 9 \text { months (adjusted mean difference }-1.09,95 \% \mathrm{Cl}-2.29 \text { to } 0.12 ; P=0.08 \text { ), at } \\
15 \text { months (adjusted mean difference }-0 \cdot 46,95 \% \mathrm{Cl}-1 \cdot 78 \text { to } 0 \cdot 86 ; P=0 \cdot 49 \text { ), } \\
\text { eight-item Morisky Medication Adherence Score: at } 9 \text { months (adjusted mean } \\
\text { difference }-0.03,95 \% \mathrm{Cl}-0.14 \text { to } 0.08 ; P=0.55 \text { ), at } 15 \text { months (adjusted mean } \\
\text { difference } 0.06,95 \% \mathrm{Cl}-0.05 \text { to } 0.17 ; P=0.27 \text { ), number of different drugs } \\
\text { prescribed in past } 3 \text { months: at } 9 \text { months (figures NR), at } 15 \text { months (adjusted } \\
\text { mean difference } 1.02,95 \% \mathrm{Cl} 0.97 \text { to } 1.06 ; P=0.46 \text { ) }\end{array}$ \\
\hline & & & & & & & $\begin{array}{l}\text { Patient-centred care: significant improvements in measures of patient-centred } \\
\text { care in intervention group vs. usual care group ( } \mathrm{PAClC} \text { score: at } 9 \text { months } \\
\text { (adjusted mean difference } 0.28,95 \% \mathrm{Cl} 0.18 \text { to } 0.38 ; P<0.0001 \text { ), at } 15 \text { months } \\
\text { (adjusted mean difference } 0.29,95 \% \mathrm{Cl} 0.16 \text { to } 0.41 ; P<0.0001 \text { ), CARE doctor } \\
\text { score: at } 9 \text { months (adjusted mean difference } 1.44,95 \% \mathrm{Cl} 0.47 \text { to } 2.41 ; \\
P=0.0035 \text { ), at } 15 \text { months (adjusted mean difference } 1.20,95 \% \mathrm{Cl} 0.28 \text { to } 2.13 \text {; } \\
P=0.0109 \text { ), CARE nurse score: at } 9 \text { months (data not collected), at } 15 \text { months } \\
\text { (adjusted mean difference } 1.11,95 \% \mathrm{Cl} 0.03 \text { to } 2.19 ; P=0.044 \text { ), Patients } \\
\text { reporting they almost always discuss the problems most important to them in } \\
\text { managing their own health: at } 9 \text { months (adjusted mean difference } 1.60,95 \% \\
\mathrm{Cl} 1.27 \text { to } 2.01 ; P=0.0001 \text { ), at } 15 \text { months (adjusted mean difference } 1.85,95 \%\end{array}$ \\
\hline
\end{tabular}




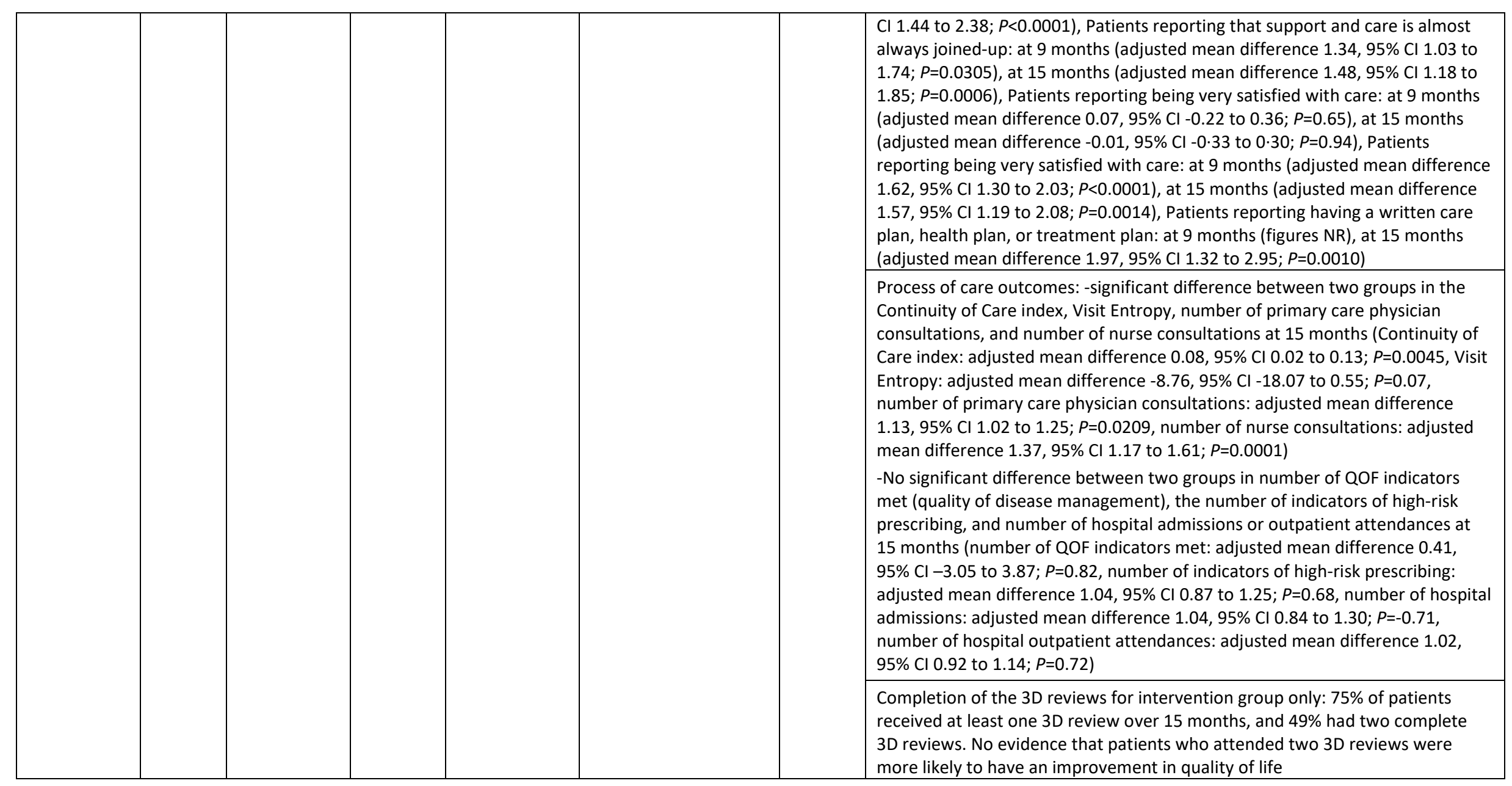


Table 1. Continued

\begin{tabular}{|c|c|c|c|c|c|c|c|}
\hline $\begin{array}{l}\text { Author, } \\
\text { country }\end{array}$ & $\begin{array}{l}\text { Study } \\
\text { type }\end{array}$ & $\begin{array}{l}\text { Study } \\
\text { settings }\end{array}$ & $\begin{array}{l}\text { Sample } \\
\text { size of } \\
\text { analysed } \\
\text { patients }\end{array}$ & $\begin{array}{l}\text { Intervention } \\
\text { provider }\end{array}$ & $\begin{array}{l}\text { Description of } \\
\text { intervention }\end{array}$ & $\begin{array}{l}\text { Follow- } \\
\text { up } \\
\text { period }\end{array}$ & Measured outcomes \\
\hline \multirow[t]{3}{*}{$\begin{array}{l}\text { Sloeserwij et } \\
\text { al. (42), } \\
\text { Netherlands }\end{array}$} & \multirow[t]{3}{*}{ CBA } & \multirow{3}{*}{$\begin{array}{l}\text { Intervention } \\
\text { in } 9 \text { general } \\
\text { practices, } \\
\text { usual care in } \\
\text { another } 10 \\
\text { general } \\
\text { practices, } \\
\text { and usual } \\
\text { care plus in } \\
\text { another } 6 \\
\text { general } \\
\text { practices }\end{array}$} & \multirow[t]{3}{*}{11,928} & \multirow{3}{*}{$\begin{array}{l}\text { Specially } \\
\text { trained non- } \\
\text { dispensing } \\
\text { pharmacists } \\
\text { integrated in } \\
\text { general } \\
\text { practices }\end{array}$} & \multirow{3}{*}{$\begin{array}{l}\text { Intervention group: } \\
\text { PBP provided } \\
\text { medication therapy } \\
\text { management services } \\
\text { both at patient level } \\
\text { (e.g. clinical } \\
\text { medication review and } \\
\text { medication } \\
\text { reconciliations) and } \\
\text { practice level (e.g. } \\
\text { quality improvement } \\
\text { projects) } \\
\text { Control group: usual } \\
\text { care provided by } \\
\text { general practitioners } \\
\text { and community } \\
\text { pharmacists, or usual } \\
\text { care plus provided by } \\
\text { general practitioners } \\
\text { and community } \\
\text { pharmacists who had } \\
\text { trained in performing } \\
\text { medication reviews }\end{array}$} & \multirow[t]{3}{*}{$\begin{array}{l}12 \\
\text { months }\end{array}$} & $\begin{array}{l}\text { Medication-related hospitalisations:- lower rate of medication-related } \\
\text { hospitalisations in intervention group vs. usual care group (adjusted rate ratio } \\
0.68,95 \% \mathrm{Cl} 0.57 \text { to } 0.82 \text { ) } \\
\text { - No difference in rate of medication-related hospitalisations in intervention } \\
\text { group vs. usual care plus group (adjusted rate ratio } 1.05,95 \% \mathrm{Cl} 0.73 \text { to } 1.52 \text { ) }\end{array}$ \\
\hline & & & & & & & $\begin{array}{l}\text { Drug burden index: no differences between the intervention group and both } \\
\text { usual care groups on treatment effect on lowering drug burden index in high- } \\
\text { risk patients (adjusted treatment effects in intervention group vs usual care } \\
\text { group - } 0.02,95 \% \mathrm{Cl}-0.07 \text { to } 0.02 ; P=0.291 \text { ), (adjusted treatment effects in } \\
\text { intervention group vs usual care plus group }-0.01,95 \% \mathrm{Cl}-0.06 \text { to } 0.04 \text {; } \\
P=0.609 \text { ) }\end{array}$ \\
\hline & & & & & & & $\begin{array}{l}\text { Costs (direct primary and secondary healthcare costs and total medication } \\
\text { costs): no differences in costs in intervention group vs. usual care group (ratio } \\
\text { of primary care costs } 1.08,95 \% \mathrm{Cl} 0.99 \text { to } 1.17 ; P=0.073 \text {, ratio of secondary } \\
\text { care costs } 0.92,95 \% \mathrm{Cl} 0.65 \text { to } 1.29 ; P=0.622 \text {, ratio of medication costs } 1.04 \text {, } \\
95 \% \mathrm{Cl} 0.98 \text { to } 1.10 ; P=0.172 \text { ) }\end{array}$ \\
\hline
\end{tabular}

ACEI: angiotensin-converting enzyme, ARB: angiotensin receptor blocker, CARE: Consultation and Relational Empathy, CBA: controlled before-and-after, CI: confidence interval, D1: difference between data available for individual patients at baseline and at the end of the study for intervention group, D2: difference between data available for individual patients at

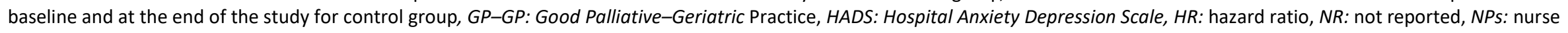

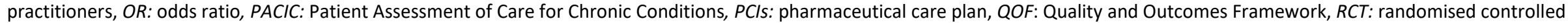
trial, SD: standard deviation, STOPP/START: Screening Tool of Older Person's Prescriptions-Screening Tool to Alert Doctors to the Right Treatment criteria 


\section{List of Figures}

- $\quad$ Figure 1. Preferred Reporting Items for Systematic Reviews and Meta-Analyses (PRISMA) flow diagram of screening process and reasons for exclusion of studies

- Figure 2. Risk of bias: review authors' judgments about each risk-of-bias item presented as percentages across all included randomised controlled trials

- $\quad$ Figure 3. Risk-of-bias summary: review authors' judgments about each risk-of-bias item for each included randomised controlled trial. (+): low risk of bias; (-): high risk of bias; (?): unclear risk of bias

- $\quad$ Figure 4. Risk-of-bias summary: review authors' judgments about each risk-of-bias item for controlled before-and-after study. (++): low risk of bias; (+): moderate risk of bias; (?):No information 